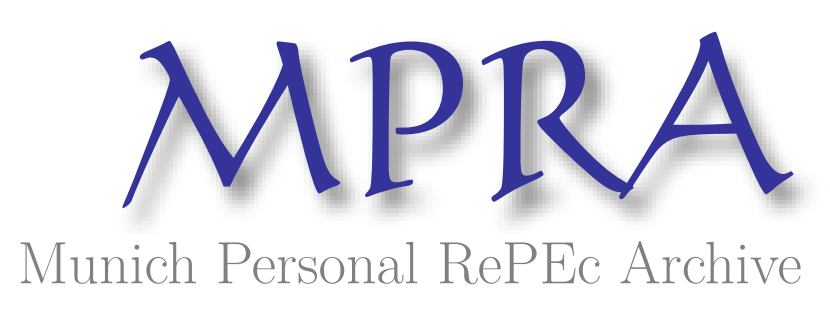

\title{
Equilibrium in a Non-Interest Open Economy
}

Mirakhor, Abbas

1993

Online at https://mpra.ub.uni-muenchen.de/56011/

MPRA Paper No. 56011, posted 20 May 2014 18:22 UTC 


\title{
Equilibrium in a Non-Interest Open Economy
}

\author{
ABBAS MIRAKHOR \\ Research Department \\ International Monetary Fund
}

\begin{abstract}
This paper analyzes an economy in which there are no interest-bearing assets, only equity shares. Equilibrium conditions are derived for the case of a closed economy, an open economy with trade in goods only, and finally one with trade in both goods and equity shares. It is shown that the rate of return to capital equilibrates savings and investment, that the differential between the domestic and foreign rates of return to equity determines the direction of capital flows, and that under a fixed exchange rate system, adjustments induced by exchange rate changes are channeled through the asset accounts.
\end{abstract}

\section{Introduction}

An Islamic financial system can be characterized as one in which there are no riskfree assets and where all financial arrangements are based on risk and return sharing. Hence, all financial assets are contingent claims ${ }^{(1)}$ and there are no debt instruments with fixed and/or predetermined rates of return. A fundamental principle that emerges from theoretical studies of such a system is that the returns to financial assets are primarily determined by the returns to the real sector. This principle implies that the rate of return of capital is the mechanism through which the demand and supply of loanable funds is equilibrated. The argument follows from the fact that the source of profit in an economy is the addition to total output, and once the labor is paid its distributive share, the residual is then divided between the entrepreneur and the surplus fund holder (Haque and Mirakhor 1987). Since this residual is an ex post variable, it follows that the return to surplus funds invested on profit-sharing basis cannot be determined ex ante. In a system where the only assets that exist are those representing ownership claims to

(1) That is the rate of return is contingent upon the outcome of the projects for which financial resources are made available. This characteristic makes an Islamic economic model an ideal setting for application of Arrow-Debru-Diamond type analysis of a stock market economy under uncertainty. 
capital stock or equity shares, ${ }^{(2)}$ the fundamental question is what is the nature of the macroeconomic equilibrium in such a system.

There is a tradition in economic theory which analyzes macroeconomic behavior in models where, unlike most macroeconomic analysis, there are no debt instruments and there is no fixed interest rate. This tradition began with the classic paper by Metzler (1951) in which the only asset was assumed to be equity shares, and this type of model and its descendents can be used to analyze non-interest economy. ${ }^{(3)}$

Khan (1986) was the first to recognize the applicability of Metzler's model to an Islamic financial system. He showed that the Islamic model of banking, "being based on principles of equity participation, may well prove to be better suited to adjusting to shocks that result in banking crises and disruptions of the payment mechanism of the country. In an equity-based system that excludes predetermined interest rates and does not guarantee the nominal value of deposits; shocks to asset positions are immediately absorbed by changes in the values of shares (deposits) held by the public in the bank. Therefore, the real values of assets and liabilities of banks in such a system would be equal at all points in time." (Khan 1986, p.19 ${ }^{(4)}$ Khan and Mirakhor (1988) and Mirakhor and Zaidi (1988) extended Khan's model to show how monetary policy can be used to stabilize an economy in which the financial system operates on the basis of the rate of return to equity shares rather than a fixed and predetermined interest rate.

It must be stressed that an Islamic system possesses a number of characteristics which distinguish it from traditional system (Khan and Mirakhor 1987, and Mirakhor 1987). The absence of a fixed and predetermined rate of interest is only one such feature. An important consequence of an equity-based system is that there is a close link between the real sector and the financial sector. Much of the theoretical studies on the financial system of Islam has emphasized this aspect because of the implications it holds for the economy. However, the studies undertaken to date have concentrated heavily on the workings of the financial sector, without relating directly its operations to real sector developments.

The purpose of this paper is to extend Khan's model to an open economy, placing special emphasis on the real sector. For this reason Section II presents a closed model in which the real sector is the source of all macroeconomic behavior in the economy. In particular, an attempt has been made to show how the rate of return to capital (the rate of profit) determines not only saving and investment behavior, but also the behavior of asset holders in the financial sector. This Section presents a nonstationary model in which the labor force is assumed to grow at an exogenously given rate and where the only available asset is ownership claims to capital in form of shares of equity. The

(2) See Taj El-Din (1985) for a description of such a system.

(3) Metzler's model has been extended in a variety of directions. A recent example is the closed economy model presented by Shane (1984). For examples of Metzlerian-type open economy models see Frenkel and Rodriguez (1975) and Claassen (1983). The closed economy model presented here is based on Uzawa (1969), and the open economy model is based on Frenkel and Rodriguez (1975). Insights into the workings of an Islamic economy can be obtained by utilizing these models as demonstrated in this paper.

(4) That an equity-based system has desirable features that improve the shock-absorption adjustment capacity of the economy has been shown by other studies; see, for example, Shane (1984) and Cole (1988). 
model is then opened to trade in assets and equity shares. Whereas Khan's model dealt primarily with the banking system in an economy where deposits represented equity shares in the banking system-so that shares were in effect treated as money-the openeconomy model presented in Section II introduces money and equity shares explicitly as two different forms of assets which comprise the asset holders' portfolio. A key assumption of the open-economy model is that trade in assets can only take place in equities. This assumption is necessary as in an Islamic system there can be no fixed rate assets such as bonds, so that equities are the only domestic asset which the foreign asset holders can purchase. Furthermore, it is assumed that domestic residents do not require foreign interest-based assets. Finally Section III contains some concluding comments.

\section{Models of an Interest-Free Economy}

\section{The Closed Economy Model}

Assume that in a given period the economy produces output described by a linear homogenous production function

(1) $\mathrm{Q}=\mathrm{F}(\mathrm{K}, \mathrm{L})$

where $\mathrm{L}$ is the quantity of labor services employed and $\mathrm{K}$ is an index of real capital. ${ }^{(5)}$ Per capita output $\mathrm{q}=\frac{\mathrm{Q}}{\mathrm{L}}$ is then a function of capital-labor ratio $\mathrm{k}=\frac{\mathrm{K}}{\mathrm{L}}$ as in (2)

(2) $q_{t}=f(k)$

where $\mathrm{f}^{\prime}(\mathrm{k})>0$ and $\mathrm{f}^{\prime \prime}(\mathrm{k})<0$, for all $\mathrm{k}>0$.

Under full employment conditions the rate of return to capital (the rate of profit of business firms) $r$ and the wage rate $w$ are given by (3) and (4)

(3) $r=f^{\prime}(k)$

(4) $w=f(k)-k f^{\prime}(k)$

The aggregate economy is composed of two types of economic units, business firms and households. All capital stock is owned by households whose ownership claim is represented by equity securities (common stocks). Owners do not hold capital directly. In Islamic profit-sharing arrangements business firms exercise direct control over capital by employing it in cooperation with labor. Households receive income in the form of wages for labor and returns to their equities and divide their income between consumption and increasing their asset holdings. Aggregate demand is composed of household consumption and the level of investment planned by the business firms. National income is equal to the returns to factors of production, which then determine the level of actual aggregate demand actual consumption and investment. When planned and actual aggregate demands are equal the economy is said to be in short-run equilibrium, and the rate of capital accumulation is determined by a level of aggregate demand corresponding to such an equilibrium level.

(5) An index of real capital can be constructed by measuring the earning capacity of the firm (profits to be earned) as the short-run production function shifts. See Uzawa (1969). 
Assuming homogenous quantities of labor and capital, and that the aggregate behavior of households and business in the economy can be explained in terms of a representative household and business firm, aggregate income, $\mathrm{Y}$, is given by:

(5) $\mathrm{Y}=\mathrm{W}+\mathrm{D}+\mathrm{G}$

where $\mathrm{W}, \mathrm{D}$, and $\mathrm{G}$ are the wages bill, dividends and expected capital gains respectively. The value of the equity shares held by households is

(6) $\mathrm{V}=\mathrm{P}^{\mathrm{e}} \mathrm{E}$

where $\mathrm{P}^{\mathrm{e}}$ represents the price of shares and $\mathrm{E}$ the number of shares of equity. The rate of return to equity holding prevailing in the equity market is expressed as:

(7) $\mathrm{r}^{\mathrm{m}}=\frac{\mathrm{D}+\mathrm{G}}{\mathrm{V}}$

Demand for new equity shares, i.e., the number of new shares desired by households is given by (8)

(8) $E^{D}=\frac{S-G}{P^{e}}$

where $E^{D}=d E^{D}$ and $S$ is the savings of households and is given by (9)

(9) $\mathrm{S}=\mathrm{s}\left(\mathrm{r}^{\mathrm{m}}\right) \mathrm{Y}$

where $s\left(r^{m}\right)$ is the average propensity to save ${ }^{(6)}$. Aggregate output is distributed as

(10) $\mathrm{Q}=\mathrm{W}+\mathrm{D}+\mathrm{R}$

where $\mathrm{R}$ is the market value of the portion of the profits retained by firms for additional investment.

The supply of new shares to be issued by firms is given by:

(11) $E^{S}=\frac{I-R}{P^{\mathrm{e}}}$

where $E^{S}=\mathrm{dE}^{S}$ and $\mathrm{I}$ is the desired investment by firms.

Investment is determined by a marginal efficiency schedule of the LucusTreadway-Uzawa type ${ }^{(7)}$ with the Penrose function $\mathrm{i}=\mathrm{i}(\mathrm{z})$ where $\mathrm{z}=\frac{\dot{\mathrm{K}}}{\mathrm{K}}$, i.e. the rate of growth of total physical capital and $i=\frac{I}{K}$

(6) It is assumed here that the average propensity to save is a positive function of the market rate of return.

(7) See Penrose (1959), Uzawa (1968, 1969), Lucus (1969), Treadway (1969), and Frenkel and Rodriguez (1975). 
The Penrose function can be interpreted in terms of the marginal cost of investment. The relationship between the investment-capital ratio and the rate of capital accumulation, i.e., $\mathrm{i}=\mathrm{i}(\mathrm{z})$ requires that

$$
\text { (12) } \frac{\mathrm{di}}{\mathrm{dz}}>0 \text { and } \frac{\mathrm{d}^{2} \mathrm{i}}{\mathrm{dz}^{2}}>0 \text { for all } \mathrm{z}>0
$$

The conditions in (12) reflect the scarcity of entrepreneurial ability and that the higher the rate of increase in real capital the higher is investment, as well as the fact that the marginal cost of investment is increasing.

The optimum level of $\mathrm{z}$, the rate of increase in capital, is a function of the marginal product of capital (the rate of profit) $r$ and the market rate of return to equity $r^{m}$ prevailing in the equity market ${ }^{(8)}$ Since $\mathrm{i}=\mathrm{i}(\mathrm{z})$ and $\mathrm{z}=\mathrm{z}\left(\mathrm{r}, \mathrm{r}^{\mathrm{m}}\right)$ then

$$
\begin{aligned}
& \text { (3) } z=z\left(r, r^{m}\right) \\
& \text { (4) } i=i\left(r, r^{m}\right)
\end{aligned}
$$

where

$$
\text { (15) } \frac{\partial \mathrm{z}}{\partial \mathrm{r}} \text { and } \frac{\partial \mathrm{i}}{\partial \mathrm{r}}>0 ; \frac{\partial \mathrm{z}}{\partial \mathrm{r}^{\mathrm{m}}} \text { and } \frac{\partial \mathrm{i}}{\partial \mathrm{r}^{\mathrm{m}}}<0
$$

Equation (13) and (14) can be graphically represented as in Figure 1 for a given rate of profit $r$. The rate of capital accumulation $z\left(r, r^{m}\right)$ can be positive or negative depending on whether the market rate of return is smaller or larger than the rate of profit r. Also, at a given rate of profit the firms undertake additional investment depending on the magnitude of the market rate of return to equity relative to the rate of profit. In an efficient equity market no firm will be able to obtain finance for investment projects that do not promise to yield a rate of return at least as large as the prevailing market rate of return on shares.

In an economy described above the equilibrium condition for the goods market is

(16) $Q=C+I$

The labor market is in equilibrium when there is full employment, i.e.,

(17) $\mathrm{L}=\mathrm{N}$

where $\mathrm{N}$ is the quantity of labor employed. The labor force is assumed to grow at $n$ exogenously given rate, $n=\frac{\dot{N}}{N}$ and the rate of capital accumulation is given as $\mathrm{z}=\frac{\dot{\mathrm{K}}}{\mathrm{K}}$ defined relative to the equilibrium investment-capital ratio i through the Penrose curve.

The equity market is in equilibrium when

(8) For discussions on the determination of optimum path of $z$, see Uzawa (1969). 
(18) $E^{D}=E^{S}$

and per capita output is given by (2) as $\mathrm{q}=\mathrm{f}(\mathrm{k})$. National income is defined as

(19) $Y=W+r^{m} V$

Dividing (19) by $\mathrm{N}$ to convert into per capita terms yields

(20) $y=w+r^{m} v$

If we assumed that capital gains $\mathrm{G}$ always reflect retained profits output will equal national income as in

(21) $y=q=f(k)$

The short-run equilibrium for this economy requires that

(22) $I=S$

or in terms of investment-capital ratio and savings per unit of capital (as well as in per capita terms)

(23) $i\left(r^{m}, r\right)=s\left(r^{m}\right) \frac{y}{k}$

that is planned savings must equal planned investment. Equilibrium is attained at a market rate of return $\mathrm{r}^{\mathrm{m}}$ which will equate the level of investment per unit of real capital desired by the firms and the amount of savings per unit of real capital that the households are willing to save at the market rate. Figure 2 is a graphic representation of investment and saving schedules of equation (23) The vertical axis shows the market rate of return, and the horizontal axis shows the desired investment or desired saving per unit of capital The intersection of the two curves II and SS determines the equilibrium market rate of return. While a change in the market rate of return causes a movement along the curves, a change in the rate of profit $r$ causes the curves to shift. An increase in the capital-labor ratio $k$ reduces the marginal product of capital (the rate of profit) $r$ causing a shift of II downward and to the left. The same increase in k reduces average product $y / k$ of capital, causing an upward shift in the SS curve. As a result, investment declines but the market rate of return may or may not decline depending on the way the two curves shift.

The long-run equilibrium of the system depends only on the rate of growth of the labor force, $\mathrm{n}$. The system will remain at a steady state if, and only if, the rate of investment per unit of capital is at a level $i(n)$ which corresponds to the exogenously given rate of growth of labor $\mathrm{n}$. The dynamics of the economy is described by the differential equation:

(24) $\frac{\dot{\mathrm{k}}}{\mathrm{k}}=\mathrm{i}\left(\mathrm{r}^{\mathrm{m}}, \mathrm{r}\right)-\mathrm{n}$. 


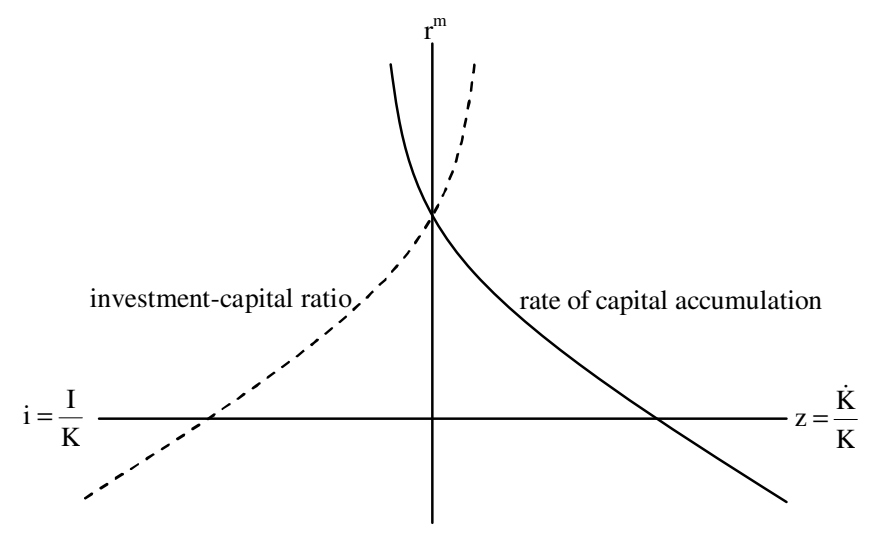

FIG. 1. Relationship between investment-capital ratio and the market rate of return and the relationship between the market rate of return and the rate of capital accumulation.

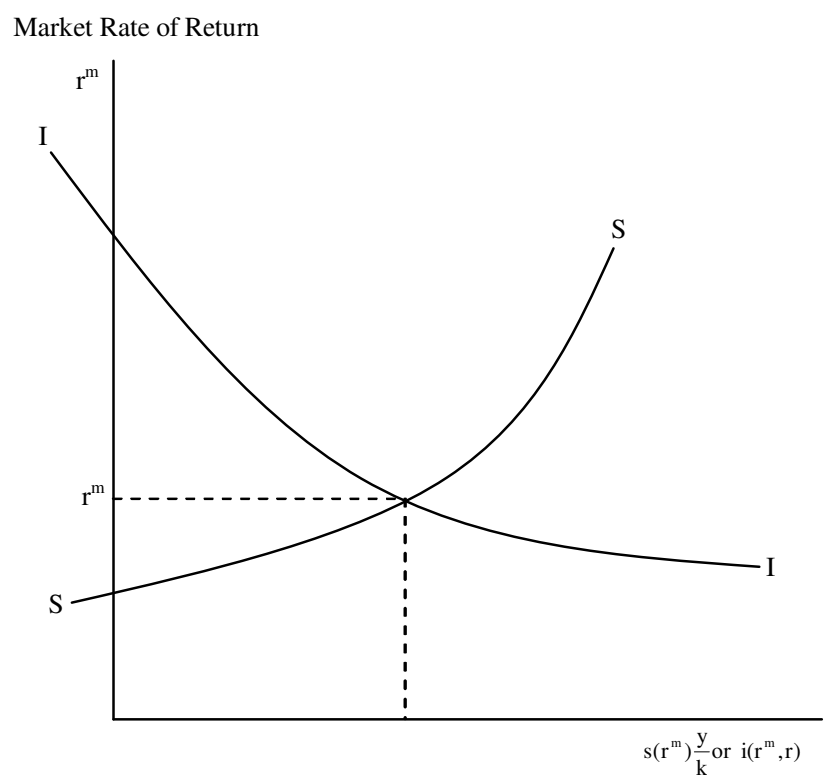

FIG. 2. Relationship between savings (and investment) per unit of capital and the market rate of return to equity. 
Designating the steady-state level of capital-labor ratio as $\mathrm{k}^{*}$, whenever $\mathrm{k}$ is lower than its long-run equilibrium level $\mathrm{k}^{*}$ then the capital-labor ratio increases, i.e., $\mathrm{k}>0$. If $\mathrm{k}$ is at a higher level than $\mathrm{k}^{*}$, then $\mathrm{k}<0$ and the capital-labor ratio declines. The longrun equilibrium level of capital-labor ratio $\mathrm{k}^{*}$ is determined by the long-run equilibrium levels of investment and savings from the following equations.

$$
\begin{aligned}
& \text { (25) } i\left(r^{*}, r^{*}\right)=i(n) \\
& \text { (26) } \left.s^{(m *)}\right) \frac{y^{*}}{k^{*}}=i(n)
\end{aligned}
$$

where $\mathrm{r}^{\mathrm{m}}$ is the long-run equilibrium market rate of return; $\mathrm{y}^{*}=\mathrm{f}\left(\mathrm{k}^{*}\right)$ and $\mathrm{r}^{*}=$ $\mathrm{f}^{\prime}\left(\mathrm{k}^{*}\right)$ are the long-run equilibrium levels of income and profit rates respectively; and $\mathrm{i}(\mathrm{n})$ is the equilibrium rate of investment corresponding to the rate of growth of labor, $n$.

The two equations (25) and (26) state that there is a pair of rates of return $\mathrm{r}^{\mathrm{m}}$ and $\mathrm{r}^{*}$ which equate the long-run desired levels of investment and savings per unit of capital. As is shown in Figure 3, the intersection of desired saving per unit of capital and desired investment per capita determine the long-run equilibrium market rate of return and capital-labor ratio. The equilibrium conditions (25) and (26) state that for any market rate of return $\left(\mathrm{r}^{*}\right)$ above its long run equilibrium level $\left(\mathrm{r}^{*}\right)$ the rate of profit $\left(\mathrm{r}^{*}\right)$ must also increase (thus $\mathrm{k}^{*}$ must decrease) in order for investment to be maintained at its long-run equilibrium level i(n). Also an increase in the market rate of return above its long-run equilibrium level must be accompanied by a higher capital-labor ratio $\left(\mathrm{k}^{*}\right)$, and thus lower average product of capital $\left(\mathrm{y}^{*} / \mathrm{k}^{*}\right)$, in order for savings to equal long-run equilibrium level of investment $i(n)$. The long-run equilibrium of the economy can be determined once the production function, consumption saving behavior, the investment function (the Penrose curve) and the rate of growth of labor (n) are specified.

The important implication of this analysis is that the assumption of a fixed and predetermined rate of interest is not necessary either for the determination of savinginvestment behavior, or for the existence of a long-run equilibrium of the economy. While it is true that the existence of a rate of time preference may be needed to determine the equilibrium consumption-saving behavior in the economy, and while its necessity or existence in an Islamic economy cannot be denied (nor is there any basis for rejecting its existence based on traditional Islamic sources), ${ }^{(9)}$ there is no strong economic-theoretic justification for assuming that the rate of time preference is fixed, predetermined and equal to the market rate of interest. ${ }^{(10)}$ One could easily and without loss of generality assume that the rate of time preference is equal to the market rate of return on equity shares. ${ }^{(11)}$

(9) By traditional sources we mean the Quran and the Traditions of the Prophet.

(10) Frank Knight (1971, pp.130-140) has shown that the neoclassical notion of time preference can also produce either negative or zero rate of discount. See also Olson and Bailey (1981) and Epstein and Hynes (1983).

(11) See for example Montiel (1986) in which the rate of time preference is equal to the marginal product of capital. 


\section{The Open Economy Model ${ }^{(12)}$}

To analyze the consequences of opening a non-interest economy to trade in goods and assets the above model can be modified and simplified. Money is introduced as an additional asset with zero nominal rate of return. Retained earnings can be dropped by assuming that holding shares in a firm that is retaining earnings is equivalent to using these earnings to buy new shares in the firm. The number of shares is assumed equal to the number of units of capital goods so that $\mathrm{E}=\mathrm{K}$. Because of our interest in the effects of trade in equity shares, the aggregate supply is assumed a function of capital, i.e.

$$
\text { (27) } \mathrm{Q}=\mathrm{F}(\mathrm{K}) \text {, where } \mathrm{F}^{\prime}=\frac{\mathrm{dF}}{\mathrm{dK}}>0 \text { and } \frac{\mathrm{d}^{2} \mathrm{~F}}{\mathrm{dK}^{2}}<0 \text {. }
$$

The rate of return to equity shares is now defined as $r=\frac{F^{\prime} P}{P_{E}}$ where $P$ is the price level, $\mathrm{P}_{\mathrm{E}}$ is the nominal price of shares, and $\mathrm{F}^{\prime} \mathrm{P}$ is the value of marginal product of capital. Defining the real price of shares as $\mathrm{p}^{\mathrm{e}}=\frac{\mathrm{P}_{\mathrm{E}}}{\mathrm{P}}$ the rate of return in real terms becomes

$$
\text { (28) } r=\frac{F^{\prime}}{p^{e}}
$$

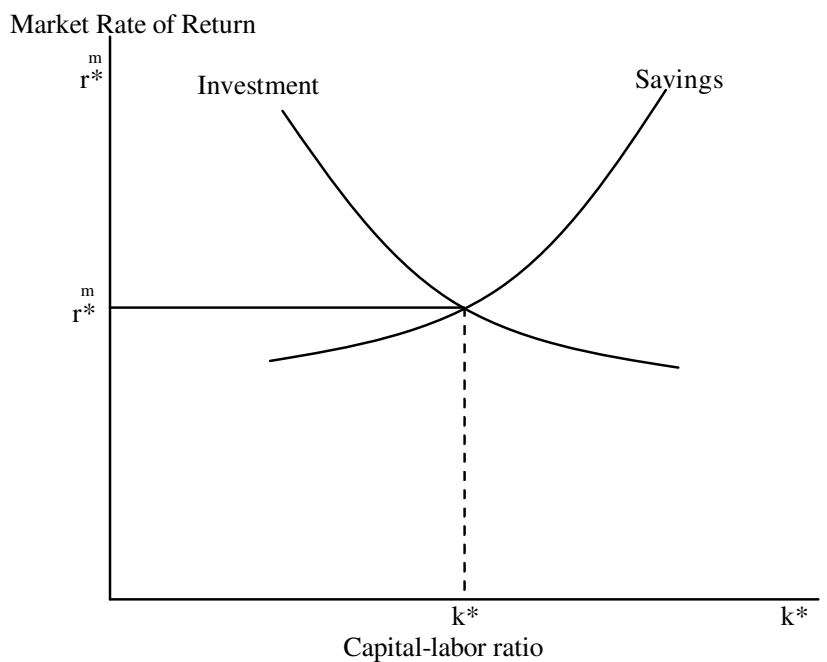

Fig. 3. Long-run equilibrium levels of capital-labor ratio and the market rate of return to equity.

(12) For further discussion of this model, see Frenkel and Rodriguez (1975), Frenkel (1976), Dorubusch (1976), and Claassen (1983). 
which along with assumptions on capital gains and profits modifies equation (14) to become $\mathrm{i}=\mathrm{i}(\mathrm{r})$ and since by definition $\mathrm{i}=\frac{\mathrm{I}}{\mathrm{K}}$ and capital stock is given in the shortrun, investment becomes a function of $\mathrm{r}$ and $\mathrm{K}$ as in (29),

(29) $\mathrm{I}=\mathrm{I}(\mathrm{r}, \mathrm{K})$ where $\frac{\partial \mathrm{I}}{\partial \mathrm{r}}<0$ and $\frac{\partial \mathrm{I}}{\partial \mathrm{K}}<0$

Real wealth is defined as $\left(p^{e} E+m\right)$, where $m=\frac{M}{P}$ is the stock of real balances. In searching for an optimal portfolio the individuals adjust their holding of real cash balances and equity until the actual and desired mix of the two assets are equal. Such an equilibrium is represented in Figure 4. If the wealth constraint is $m_{1} n_{1}$ instead of $m n$, the desired mix will be at point $B$ where individuals will attempt to increase their holding of money balances by reducing their equity holdings. Given (28) as the price of shares decreases, $r$ increases and the slope of $m_{1} n_{1}$ declines, causing it to rotate around point $A$ downward to the right, until it coincides with $\mathrm{mn}$ and the original equilibrium is established at point A.

Demand equations for goods, equity, and money are assumed, in real terms, to have the following form ${ }^{(13)}$

$$
\text { (30) } \mathrm{D}_{\mathrm{i}}=\mathrm{D}_{\mathrm{i}}(\mathrm{r}, \mathrm{y}, \mathrm{m})
$$

where $\mathrm{i}=1,2,3$ refer to each market for goods, equity shares, and money; and $\mathrm{m}$ refer to real income and stock of real balances, respectively. The aggregate demand for goods is the sum of consumption and investment. Equilibrium in the three markets is given by

$$
\begin{aligned}
& \text { (31) } \mathrm{Q}=\mathrm{AD}(\mathrm{r}, \mathrm{y}, \mathrm{m}) \\
& \text { (32) } \mathrm{K}=\mathrm{E}_{\mathrm{d}}(\mathrm{r}, \mathrm{y}, \mathrm{m}) \\
& \text { (33) } \mathrm{M}=\operatorname{PL}(\mathrm{r}, \mathrm{y}, \mathrm{m})
\end{aligned}
$$

where $\mathrm{Q}$ is the aggregate supply and PL represents demand for money in nominal terms. From these equations $\mathrm{P}$ and $\mathrm{r}$ can be determined. Of equation (31)-(33) only two are independent given the constraint indicated by Walras Law.

$$
\text { (34) } y=A D+p^{e}(E-K)+(L-M)
$$

Given the money supply and the level of real capital and assuming existence and stability of the system ${ }^{(14)}$ the price level of goods and the rate of return on equity shares can be determined. The long-run equilibrium is attained when real capital and money supply do not change. The conditions for long-run equilibrium can be given as when $\mathrm{y}=$ $\mathrm{AD}, \mathrm{E}=\mathrm{K}$, and $\mathrm{I}=0$. These conditions are satisfied when $\mathrm{m}=\mathrm{m}^{*}, \mathrm{r}=\mathrm{r}^{*}$ and $\mathrm{K}=\mathrm{K}^{*}$. An asterisk over the variable designates its long-run equilibrium value.

(13) See Patinkin (1965) chapters IX-XI for further explanation on the functional forms of the demand equations. (14) See Patinkin (1965) Chapter X. 
Assume that the economy is small relative to the rest of the world, that it faces a world price of goods Pf and that the exchange rate is given by

$$
\text { (35) } \mathrm{e}=\frac{\mathrm{P}}{\mathrm{P}_{\mathrm{f}}}
$$

where $\mathrm{P}$ is the domestic price level. Concentrating first on trade in goods only, the domestic money supply will increase or decrease corresponding to the balance of trade. The short-run equilibrium is given by

$$
\begin{aligned}
& \text { (36) } \mathrm{Q}=\mathrm{AD}\left(\mathrm{r}, \mathrm{y}, \frac{\mathrm{M}}{\mathrm{eP}_{\mathrm{f}}}\right)+\mathrm{T} \\
& \text { (37) } \mathrm{K}=\mathrm{E}\left(\mathrm{r}, \mathrm{y}, \frac{\mathrm{M}}{\mathrm{eP}_{\mathrm{f}}}\right)
\end{aligned}
$$

where $\mathrm{T}$ is the trade balance. From these equations $\mathrm{T}$ and $\mathrm{r}$ can be determined. The dynamic structure of the adjustment process is determined by the following pair of differential equations

(38) $\dot{\mathrm{M}}=\mathrm{eP}_{\mathrm{f}} \mathrm{T}$

(39) $\dot{\mathrm{K}}=\mathrm{I}(\mathrm{r}, \mathrm{K})$

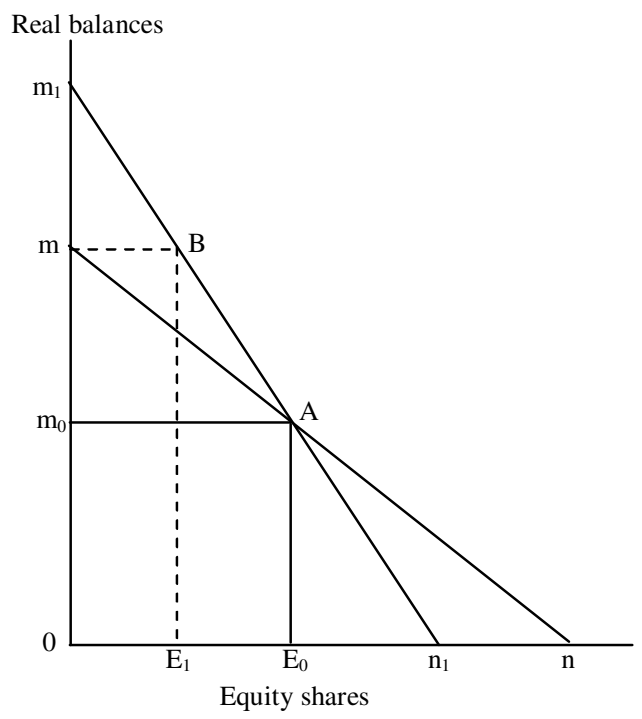

FIG. 4. Optimal portfolio mix. 
If the initial (before trade) domestic price level $\mathrm{P}$ is lower than $\mathrm{P}_{\mathrm{f}}$ when trade takes place there is an immediate increase in real balances which leads to portfolio adjustment in favor of domestic equity shares. There is also a positive trade balance. Recalling portfolio adjustment described in Figure 4 and considering equation (37), in the first phase of adjustment $\mathrm{M}$ becomes positive and $\mathrm{K}$ negative, thus lowering the rate of return and increasing investment. Increases in $\mathrm{M}$ and $\mathrm{K}$ reduce $\mathrm{T}$ and $\mathrm{K}$ and the system moves toward its long-run equilibrium position and once there, all variables attain their steady-state values with new money supply $\mathrm{M}^{*}$ and $\mathrm{P}^{*}=\mathrm{P}_{\mathrm{f}}$. Under a flexible exchange rate system and exchange rate adjusts to attain an equilibrium balance of trade and the same pre-trade long-run equilibrium will be achieved.

When trade in assets as well as goods is allowed the short-run equilibrium conditions (36) and (37) become

$$
\begin{aligned}
& \text { (40) } \mathrm{Q}=\mathrm{AD}\left(\mathrm{r}_{\mathrm{f}}, \mathrm{y}, \frac{\mathrm{M}}{\mathrm{eP}_{\mathrm{f}}}\right)+\mathrm{T} \\
& \text { (41) } \mathrm{K}=\mathrm{E}_{\mathrm{d}}\left(\mathrm{r}_{\mathrm{f}}, \mathrm{y}, \frac{\mathrm{M}}{\mathrm{eP}_{\mathrm{f}}}\right)+\mathrm{E}_{\mathrm{f}}
\end{aligned}
$$

where $r_{f}$ is the world rate of return to equity, $E_{d}$ is the domestic holding of domestic equity, and $\mathrm{E}_{\mathrm{f}}$ is the foreign holding of domestic equity and equals the difference between domestic capital and the equity claims held by domestic residents. Given K, M, and $P_{f}$, then $T$ and $E_{f}$ can be determined from equations (40) and (41). If $E_{f}$ is positive it means that the country is a debtor, and if negative it represents domestic residents' holding of foreign equity claims and the domestic economy is a creditor. It is assumed that the equities being traded internationally are homogenous. If the marginal product of capital is higher in the domestic economy then its equity shares will have a higher price and adjustment in the rate of return to equity shares takes place through adjustment in their prices.

If the domestic rate of return on equities is higher than the world rate then upon opening of trade there will be an excess demand for domestic equity which raises the price of equity and the wealth of domestic households and, along with a reduction in the rate of return, induces an instantaneous portfolio adjustment of the type described in Figure 4, where the increase in real value of assets changes the wealth constraint from $\mathrm{mn}$ to $\mathrm{m}_{1} \mathrm{n}_{1}$. The new short-run equilibrium, with a new rate of return equal to $\mathrm{r}_{\mathrm{f}}$, domestic holdings of real cash balances and equities become $\mathrm{m}$ and $\mathrm{E}_{1}$, respectively. Thus the economy exchanges $E_{1} E_{0}$ units of equity for $m_{0} m$ of real balances with the rest of the world and the new portfolio equilibrium moves from point $\mathrm{A}$ to point $\mathrm{B}$. $^{(15)}$ With domestic rate of return greater than $r_{f}$, the foreign holding of domestic equities increases initially, i.e. E> 0 . A lower domestic rate of return and positive $\mathrm{M}$ will mean a positive $\mathrm{K}$ and a worsening trade balance, but the balance of payments will be positive because of increased demand for money, $\mathrm{M}>0$. Given a non-oscillating adjustment mechanism, if the initial shock from capital movements is not very strong the

(15) See Frenkel and Rodriguez (1975) and Frenkel and Fischer (1974). 
adjustment process will proceed. ${ }^{(16)}$ An increase in real capital and in payments of return to foreign holdings of domestic equity, which in real terms equals $\mathrm{F}^{\prime} \mathrm{E}_{\mathrm{f}}$, will lead to positive trade accounts.

Considerations of payments for return on foreign holdings of domestic equities, that is $y=F(K)-F^{\prime} E_{f}$, modifies equations (40) and (41) to become ${ }^{(17)}$.

$$
\begin{aligned}
& \text { (42) } Q=\left(r_{f},\left[F(K)-F^{\prime} E_{f}\right], \frac{M}{e_{f}}\right)+T \\
& \text { (43) } K=E_{d}\left(r_{f},\left[F(K)-F^{\prime} E_{f}\right], \frac{M}{e_{f}}\right)+E_{f}
\end{aligned}
$$

Equations (42) and (43) yield the following simultaneous equation system

$$
\text { (44) }\left[\begin{array}{cc}
1 & -\frac{\partial A D}{\partial y} F^{\prime} \\
0 & 1-\frac{\partial E_{d}}{\partial y} F^{\prime}
\end{array}\right]\left[\begin{array}{c}
D T \\
d E_{f}
\end{array}\right]=\left[\begin{array}{c}
F^{\prime}(K)-\frac{\partial A D}{\partial y}\left(F^{\prime}-F^{\prime \prime} E_{f}\right) \\
1-\frac{\partial E_{d}}{\partial y}\left(F^{\prime}-F^{\prime} E_{f}\right)
\end{array}\right] d K+\left[\begin{array}{c}
-\frac{\partial A D}{\frac{\partial M}{e P_{f}}} \\
-\frac{\partial E}{\partial M} \\
e P_{f}
\end{array}\right] d M
$$

The effects of changes in $M$ and $K$ on the short-run equilibrium values of $T$ and $E_{f}$ can be determined using (44), which yields ${ }^{(18)}$

$$
\text { (45) } \frac{\mathrm{dT}}{\mathrm{dK}}=\frac{1}{\mathrm{D}}\left|\begin{array}{cc}
\mathrm{F}^{\prime}-\frac{\partial \mathrm{AD}}{\partial \mathrm{y}}\left(\mathrm{F}^{\prime}-\mathrm{F}^{\prime \prime} \mathrm{E}_{\mathrm{f}}\right) & -\frac{\partial \mathrm{AD}}{\partial \mathrm{y}} \mathrm{F}^{\prime} \\
1-\frac{\partial \mathrm{E}_{\mathrm{d}}}{\partial \mathrm{y}}\left(\mathrm{F}^{\prime}-\mathrm{F}^{\prime \prime} \mathrm{E}_{\mathrm{f}}\right) & 1-\frac{\partial \mathrm{E}_{\mathrm{d}}}{\partial \mathrm{y}} \mathrm{F}^{\prime}
\end{array}\right|>0
$$

(16) See Dornbusch $(1971,1976)$, and Frenkel $(1971,1975)$.

(17) Since $Q=F(K), d Q=F^{\prime} d K$ and $y=F(K)-F^{\prime} E_{f}$ then dy $=F^{\prime} d k-F^{\prime \prime} E_{f} d K+F^{\prime} d E_{f}$

(18) To sign the expression (45) and (46) it is assumed that $F^{\prime \prime} E_{f}$ is to be zero. 


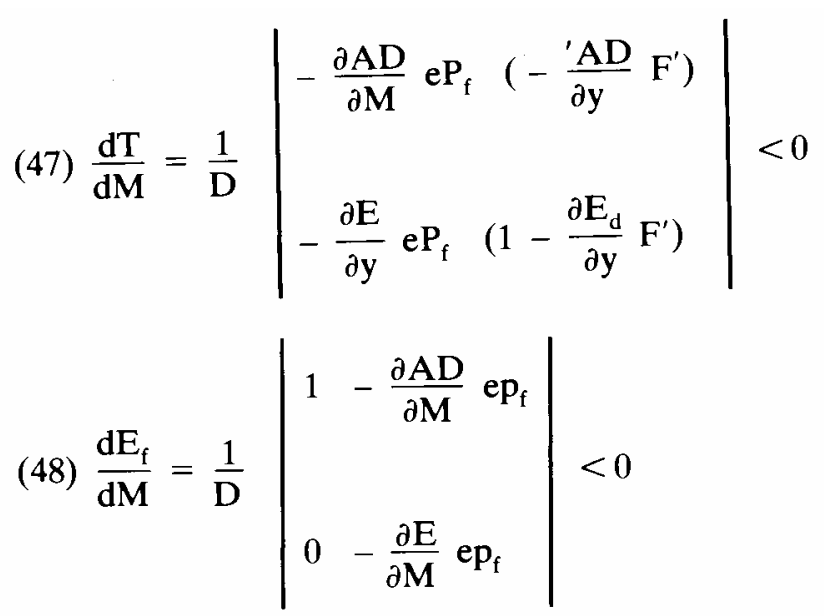

and the determinant $\mathrm{D}$ is

$$
\mathrm{D}=\left|\begin{array}{cc}
1 & \left(-\frac{\partial \mathrm{E}_{\mathrm{D}}}{\partial \mathrm{y}} \mathrm{F}^{\prime}\right) \\
0 & \left(1-\frac{\partial \mathrm{E}_{\mathrm{d}}}{\partial \mathrm{y}} \mathrm{F}^{\prime}\right)
\end{array}\right|<0
$$

The results attained in (45) - (48) can be explained as follows: an increase in real capital increases supplies of goods and equity shares but, because the income effect is normally positive and less than one, the increase in demand for them is less than the increase in their supplies; therefore foreign demand for goods and equities must increase to restore equilibrium in the market. Thus, the trade balance and foreign holdings of domestic equity respond positively to changes in capital. On the other hand (47) and (48) are negative. The reason is that an increase in money supply increases real balances, and this in turn raises the domestic demand for goods and equity shares. However, since the supply of goods and equity do not change, the foreign demand for goods and foreign equity holdings of domestic assets must decline for the markets to clear. ${ }^{(19)}$ Reductions in foreign holdings of domestic equity, of course, lower return payments to foreign holders of equity shares.

The dynamic adjustment equations are

(19) Here we have not suggested how the stock of money is increased. The adjustment process depends on whether the change in money supply has "inside" or "outside" sources and whether it is in the form of "once-for-all" change or in the form of continuous open-market operation in which the government buys and sells equities in order to change the money supply. Moreover, the adjustment process depends also on the way in which the government disposes of earnings from its equity holdings and how the households view the government holdings of equity shares. Nonetheless results obtained in equations (47) and (48) are general and should hold under various assumptions. For further discussion see Metzler (1951, 1952), Mundell (1960), Waud (1970), and Frenkel and Rodriguez (1975). 
(49) $\dot{\mathrm{K}}=\mathrm{I}\left(\mathrm{r}_{\mathrm{f}}, \mathrm{K}\right) ; \frac{\partial \mathrm{I}}{\partial \mathrm{r}_{\mathrm{f}}}<0$ and $\frac{\partial \mathrm{I}}{\partial \mathrm{K}}<0$

(50) $\dot{\mathrm{M}}=\mathrm{eP}_{\mathrm{f}} \mathrm{L}\left(\mathrm{r}_{\mathrm{f}}, \mathrm{y}, \frac{\mathrm{M}}{\mathrm{eP}_{\mathrm{f}}}\right)-\mathrm{M}$

Equation (50) expresses surplus or deficit balance of payment and is the familiar monetary approach to balance of payments. Linearization of differential equations (49) and (50) yields the following coefficient matrix ${ }^{(20)}$

(51) $A=\left[\begin{array}{lc}\frac{\partial I}{\partial K} & 0 \\ e P_{f} \frac{\partial L}{\partial y}\left(F^{\prime}-F^{\prime \prime} E_{f}-F^{\prime} \frac{d E_{f}}{d K}\right) & \frac{\partial L}{\partial M}-1\end{array}\right]$

the determinant of this matrix is

$$
|\mathrm{A}|=\frac{\partial \mathrm{I}}{\partial \mathrm{K}}\left(\frac{\partial \mathrm{L}}{\partial \mathrm{M}}-1\right)>0
$$

As the trace of (51) is negative the equilibrium is locally stable as shown in Figure 5. The system is also globally stable if the $\mathrm{a}_{21}$ element of (51) is everywhere positive and its $\mathrm{a}_{22}$ element is everywhere negative. The discriminant of (51) is (trace) ${ }^{2}-4|\mathrm{~A}|$, i.e.,

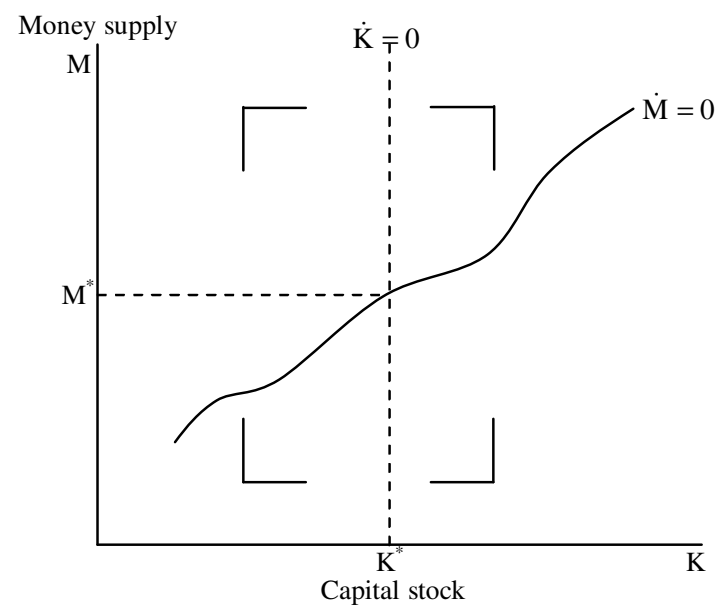

FIG. 5. The dynamic adjustment path.

(20) For the $a_{21}$ element of matrix $A$ recall that $d y=F^{\prime} d k-F^{\prime \prime} E_{f} d K-F^{\prime} E_{f}$, and dividing by $d K$ yields $\left(F^{\prime}-F^{\prime \prime} E_{f}-F^{\prime} d E_{f} / d K\right)$ 


$$
\mathrm{D}=\left(\frac{\partial \mathrm{I}}{\partial \mathrm{K}}+\frac{\partial \mathrm{L}}{\partial \mathrm{M}}-1\right)^{2}-4\left[\frac{\partial \mathrm{I}}{\partial \mathrm{K}}\left(\frac{\partial \mathrm{L}}{\partial \mathrm{M}}-1\right)\right]=\left(\frac{\partial \mathrm{I}}{\partial \mathrm{K}}-\frac{\partial \mathrm{L}}{\partial \mathrm{M}}+1\right)^{2} \geq 0
$$

both roots are real and there are no oscillations in the adjustment process.

Given an initial position and the fact that the adjustment path is non-oscillating, the properties of the adjustment process can be explained. The long-run equilibrium is obtained when $\dot{\mathrm{K}}=0$ and $\dot{\mathrm{M}}=0$. By Wairas Law we have

(52) $\mathrm{eP}_{\mathrm{f}}(\mathrm{y}-\mathrm{AD})+\mathrm{P}_{\mathrm{E}}(\dot{\mathrm{K}}-\mathrm{E})+\dot{\mathrm{M}}=0$

Substituting $\dot{\mathrm{M}}=0$ and $\dot{\mathrm{K}}=0$ in (52) with given $\mathrm{P}_{\mathrm{f}}$ and $\mathrm{r}_{\mathrm{f}}$ and the short-run equilibrium conditions, the long-run equilibrium of the economy with trade in goods and assets are

$$
\text { (53) }\left\{\begin{array}{l}
\mathrm{F}(\mathrm{K})=\mathrm{AD}\left(\mathrm{r}_{\mathrm{f}},\left[\mathrm{F}(\mathrm{K})-\mathrm{F}^{\prime} \mathrm{E}_{\mathrm{f}}\right], \frac{\mathrm{M}}{\mathrm{eP}}\right)+\mathrm{T} \\
\mathrm{K}=\mathrm{E}_{\mathrm{d}}\left(\mathrm{r}_{\mathrm{f}},\left[\mathrm{F}(\mathrm{K})-\mathrm{F}^{\prime} \mathrm{E}_{\mathrm{f}}\right], \frac{\mathrm{M}}{\mathrm{e} \mathrm{P}_{\mathrm{f}}} ;+\mathrm{E}_{\mathrm{f}}\right. \\
\mathrm{I}(\mathrm{r}, \mathrm{K})=0 \\
\mathrm{~F}^{\prime} \mathrm{E}=\mathrm{T} \\
\mathrm{K}=\mathrm{K}^{*}, \mathrm{M}=\mathrm{M}^{*}, \mathrm{E}=\mathrm{E}^{*}, \text { and } \mathrm{T}=\mathrm{T}^{*}
\end{array}\right.
$$

To compare (53) with the initial position of the economy before trade we recall the long-run equilibrium without trade which is as follows:

$$
\text { (54) }\left\{\begin{array}{l}
\mathrm{F}(\mathrm{K})=\mathrm{AD}\left[\mathrm{r}, \mathrm{F}(\mathrm{K}), \frac{\mathrm{M}}{\mathrm{P}}\right] \\
\mathrm{K}=\mathrm{E}\left[\mathrm{r}, \mathrm{F}(\mathrm{K}), \frac{\mathrm{M}}{\mathrm{P}}\right. \\
\mathrm{I}(\mathrm{r}, \mathrm{K})=0 \\
\mathrm{~T}=0 \\
\mathrm{~K}=\mathrm{K}^{*}, \mathrm{M}=\mathrm{M}^{*} \text { and } \mathrm{r}=\mathrm{r}^{*}
\end{array}\right.
$$

Clearly the long-run equilibrium positions of the economy before and after trade are different. When the country begins to trade in goods and equity claims foreign investors will hold domestic equity shares if the rate of return on domestic equity is higher than the world rate of return on similar assets and $E_{f}$ will be positive. But as they do so the rate of return declines (and price of equity shares increases), and the demand for goods will increase and trade account worsen) $\mathrm{T}<0$. The balance of payments, however, will be positive because the demand for money has increased and $\dot{\mathrm{M}}>0$. Lower rates of return increase investment $\dot{\mathrm{K}}>0$, as a result $\dot{\mathrm{E}}>0$. In the long-run as $\dot{\mathrm{K}}$ 
$=0$ and $\dot{\mathrm{M}}=0$ then $\dot{\mathrm{E}}=\mathbf{0} .^{(21)}$ In terms of Figure 5, the adjustment process implies that if $r>r_{f}\left(r<r_{f}\right)$ then the initial position of $\dot{K}$ and $\dot{M}$ are the area below (above) the line $\dot{\mathrm{M}}=0$ and to the left (right) of the line $\dot{\mathrm{K}}=0$.

The adjustment process described above can be used to analyze the effects of changes in the exchange rate. Since in the open-economy case the quantity of real balances is defined as $\mathrm{m}=\mathrm{M} / \mathrm{eP}_{\mathrm{f}}$ then any change in the exchange rate will have results analogous to those following changes in the nominal quantity of money. ${ }^{(22)}$ Thus, a devaluation is analogous to a one-time reduction in the nominal money supply, while a revaluation has effects parallel to those of a once-for-all increase in the nominal quantity of money. Interpreted this way no additional derivation is required for examination of the effects of changes in the exchange rate. Equation (47) and (48) above, for example, can be used to show the effects of a devaluation on short-run equilibrium values of the trade balance and capital flows. As can be seen from these equations, a devaluation should increase capital inflows, through an increase in foreign ownership of domestic equity, and improve the balance of trade. A revaluation naturally has the opposite effect.

Equations (47) and (48) also imply that the channels through which these effects are transmitted are the asset markets (equity shares and money). A devaluation raises the price level $\mathrm{P}=\mathrm{eP}_{\mathrm{f}}$ and, thereby, reduces the value of real balances (therefore real wealth), inducing an instantaneous portfolio adjustment. Figure 6 illustrates the portfolio adjustment triggered by a devaluation. With the initial equilibrium at point $\mathrm{D}$, a devaluation leads to a reduction in real wealth to a point such as $\mathrm{C}$, which then induces an instantaneous portfolio adjustment from $\mathrm{C}$ to $\mathrm{A}$ when the asset decumulation is divided between equity shares and money so as to achieve portfolio balance. ${ }^{(23)}$ As the domestic equity holders reduce their stocks of equities the price of equities is reduced, thus making them more attractive for exports. On the other hand, devaluation reduces aggregate consumption expenditure relative to income, thus leading to an improved balance of trade.

A currency revaluation has the opposite effects since, again, it is as if real balances were raised. There is an excess demand for equity shares, and as a result of an instantaneous portfolio adjustment, part of increase in real cash balances is exchanged for additional equity holdings. The monetary change, however, does not affect the capital stock, ${ }^{(24)}$ hence the level of output is fixed, but aggregate consumption expenditure increases. Additional equity holding is supplied by foreign holders of domestic equities which leads to an improvement in the capital account (by the amount of rate of return multiplied by a change in foreign holdings of domestic equities). But at the same time, due to increased consumption, the surplus (deficit) in the balance of trade is reduced (increased). These changes in the capital account reflect the once-for-all

(21) The adjustment process is reversed if the domestic rate of return on equities is lower than the foreign rate of return on similar assets.

(22) See Frenkel and Rodriguez (1975).

(23) Recall that the system is homogenous of degree zero in the nominal money stock $M$ and in the exchange rate $\mathrm{e}$, and also that the aggregate asset holders' demand for real cash balances, $\mathrm{L}$, is assumed proportional to the value of their equity holdings.

(24) See Meltzer (1951) and Frenkel and Rodriguez (1975). 
stock adjustment needed to restore portfolio balance and much of the adjustment in the short-run is channeled through the asset accounts. As the adjustment proceeds there will be a gradual decumulation of assets which will be reflected in a surplus in the capital account and deficit in the monetary account. There will also be a gradual improvement in the trade account until the adjustment process comes to an end and the long-run equilibrium is re-established.

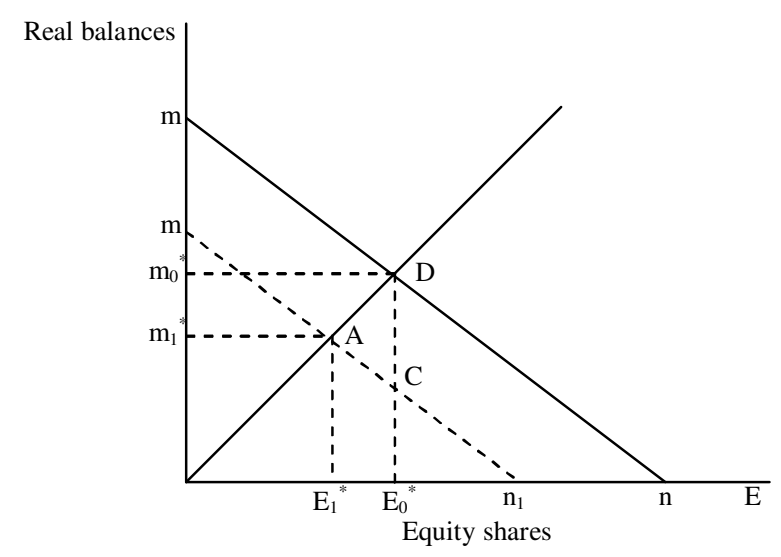

FIG. 6. Portfolio adjustment induced by changes in exchange range.

\section{Conclusions}

An Islamic system possesses a variety of characteristics which differentiates it from other economic systems. This paper has concentrated on two of these characteristics: namely that there can be no fixed-return assets and that, by implication from this, the rate of return to financial assets must be determined by return in the real sector of the economy. An open-economy model is presented in order to analyze the effects of trade in goods and assets on the macroeconomic equilibrium of the economy. Based on these two characteristics it is argued that the only assets that can exist in an Islamic economy are those which represent ownership claims to real capital. One asset that satisfies the Islamic requirements is an equity share in the form of a common stock. The model presented in this paper assumes that only equity shares can be traded internationally. Considerable emphasis has been placed on the developments in the real sector to show how the rate of return in this sector determines the macroeconomic equilibrium in the economy without the assumption of a fixed rate of interest.

Three sets of long-run equilibrium conditions are derived for a closed economy, for an open economy with trade in goods only, and finally for an open economy with trade in goods and equity shares. For the most general case, it is shown that the direction of capital flows depends crucially on the differential between the domestic and foreign rates of return to equity shares and, ultimately, on differentials in the marginal product of capital. Moreover, it was shown that trade in goods does not, in and of itself, change the long-run equilibrium of the economy, but when trade in equities is also allowed the long-run equilibrium is affected. Consequently, whereas in the first instance policy must concentrate on the adjustment process alone, in the second case policies must 
additionally be adopted to consider welfare effects of capital movements ${ }^{(25)}$, as well as to reflect a desirable adjustment process. It was also shown that under a fixed exchange rate regime much of the adjustment process induced by changes in exchange rate will be channeled through the asset accounts. The main conclusion of this paper is that the absence of interest-bearing assets does not hamper macroeconomic analysis or the workings of the economic system, in closed- or open- economy models. Standard macro-economic analysis can be carried out to determine the conditions which must exist for a non-interest economy to reach its equilibrium.

\section{Acknowledgement}

The author would like to thank Ghassem Salehkhou, Mohsin S. Khan and Jagdeep S. Bhandari for their helpful comments.

\section{References}

Claassen, E., The Nominal and Real Exchange Rate in a Quantity-Theoretical Two-Country Model, in E. Claassen and P. Salin (eds.), Recent Issues in the Theory of Flexible Exchange Rates, Amsterdam: North-Holland, 1983.

, and Salin, P. (eds.), Recent Issues in the Theory of Flexible Exchange Rates, Amsterdam: North-Holland, 1983.

, Recent Issues in International Monetary Economics, Amsterdam: North-Holland, 1976.

Cole, H., Financial Structure and International Trade, International Economic Review, Vol. 29, 1988.

Dornbusch, R., Open Economy Macroeconomics, New York: Basic Books, 1980.

Note on Growth and the Balance of Payments, Canadian Journal of Economics, Vol. 4, 1971.

, A Portfolio Balance Model of the Open Economy, Journal of Monetary Economics, Vol. $1,1975$.

Capital Mobility. Flexible Exchange Rates and Macroeconomic Equilibrium. in E. Claassen and P. Salin (eds.). Recent Issues in International Monetary Economics, Amsterdam: North Holland, 1976.

Devaluation, Money, and Nontraded Goods, American Economic Review, Vol. 63, 1973.

Epstein, L. and Allen Hynes, J., The Rate of Time Preference and Dynamic Economic Analysis, Journal of Political Economy, Vol. 91, 1983.

Fischer, S. and Frenkel, J.A., Investment, the Two-Sector Model and Trade in Debt and Capital Goods, Journal of International Economics, Vol. 2, 1972. , Interest Rate Equalization and Patterns of Production, Trade and Consumption in a Two Country Growth Model, Economic Record, Vol. 50, 1974.

Frenkel, J.A., Adjustment Mechanism and the Monetary Approach to the Balance of Payments: A Doctrinal Perspective, in Claassen and Salin (eds.), Recent Issues in International Monetary Economics, Amsterdam: North-Holland, 1976.

, A Theory of Money and Trade and the Balance of Payments in a Model of Accumulation, Journal of International Economy, Vol. 1, 1971.

, A Dynamic Analysis of Balance of Payments in a Model of Accumulation, in Jacob

A. Frenkel and Harry Johnson (eds.), The Monetary Approach to the Balance of Payments, London: George Allen and Unwin, 1976.

, and Johnson, H.G., The Monetary Approach to the Balance of Payments, London: George Allen and Unwin, 1976.

, and Fischer, S., International Capital Movements Along Balanced Growth Paths: Comments and Extensions, Economic Record, Vol. 48, 1972.

(25) Welfare effects of capital movements and its controls were not analyzed here but they are well known, see for example Swoboda (1976). 
and Rodriguez, C., Portfolio Equilibrium and the Balance of Payments: A Monetary Approach, American Economic Review, Vol. 65, 1975.

Haque, N.U. and Abbas Mirakhor, Saving Behavior in an Economy Without Fixed Interest, in Khan and Mirakhor (eds.), Theoretical Studies in Islamic Banking and Finance, Houston: Book Distribution Center, 1987.

, Optimal Profit-Sharing Contracts in an Interest-Free Islamic Economy, in Khan and Mirakhor (eds.), Theoretical Studies in Islamic Banking and Finance, Houston: Book Distribution Center, 1987.

Iqbal, Z. and Mirakhor, A., Islamic Banking, IMF Occasional Paper No. 49, 1987.

Khan, Mohsin, S., Islamic Interest-Free Banking, IMF Staff Papers, Vol. 33, 1986.

Principles of Monetary Policy in an Islamic Framework, Paper prepared for the International Institute of Islamic Economics, Islamabad, Pakistan, July 1987.

, and Abbas Mirakhor, Theoretical Studies in Islamic Banking and Finance, Houston: Book Distribution Center, 1987.

, The Financial System and Monetary Policy in an Islamic Economy, Journal of King Abdulaziz University: Islamic Economics, Vol. 1, 1989.

Knight, F., Risk, Uncertainty and Profit, Chicago: University of Chicago Press, 1971.

Locus, R.E., Adjustment Costs and the Theory of Supply, The Journal of Political Economy, August 1969.

Metzler, Lloyd, A., Wealth, Savings and the Rate of Interest, Journal of Political Economy, Vol. 59, 1951.

Reply, Journal of Political Economy, Vol. 60, 1952.

Mirakhor, A., The Economic System in an Islamic Society, Middle East Insight, Vol. 5, 1987. , and Iqbal Zaidi, Stabilization and Growth in an Open Islamic Economy, IMF, WP No. $22,1988$.

Montiel, P., An Optimizing Model of Household Behavior Under Credit Rationing, IME Staff Papers, Vol. 33, 1986.

Mundell, R., The Public Debt, Corporate Income Taxes and the Rate of Interest, Journal of Political Economy, Vol. 68, 1960.

Olson, M. and Bailey, M.J., Positive Time Preference, Journal of Political Economy, Vol. 89, 1981.

Patinkin, D., Money, Interest, and Prices, second edition, New York: Harper and Row, 1965.

Penrose, E.T., The Theory of Growth of the Firm, Oxford: Blackwell, 1959.

Shane, M., Capital Markets and the Dynamics of Growth, American Economic Review, Vol. 64, 1984

Solow, R.M., Capital Theory and the Rate of Return, Amsterdam: North Holland, 1963. , A Contribution to the Theory of Economic Growth, Quarterly Journal of Economics, Vol. 70, 1965.

Swoboda, A.K. (ed.) Capital Movements and Their Controls, Leiden: A.W. Sijthoff, 1976.

Taj El-Din, S.I, Towards an Islamic Model of Stock Market (in Arabic), Journal of Research in Islamic Economics, Vol. 3, 1985.

Treadway, A.B., On Entrepreneurial Behavior and the Demand for Investment, Review of Economic Studies, 1969.

Tobin, J., Money and Economic Growth, Econometrica, Vol. 33, 1965.

A General Equilibrium Approach to Monetary Theory, Journal of Money, Credit, and Banking, Feb. 1969.

A Dynamic Aggregativc Model, Journal of Political Economy, Vol. 63, 1955.

Uzawa, H., Time Preference and the Penrose Effect in a Two-class model of Economic Growth, Journal of Political Economy, Vol. 77, 1969.

The Penrose Effect and Optimum Growth, Economic Studies, Vol. 19, 1968

Wand, R.N., Inflation, Unemployment, and Economic Welfare, American Economic Review, Vol. 60, 1970. 


\title{
التوازن في اقتصاد مفتوح خال من الربا
}

\author{
عباس مير اخور \\ قسم البحوث - صندوق النقد الدولي مترو
}

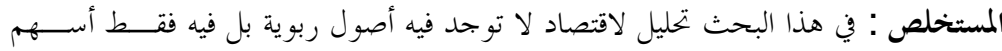

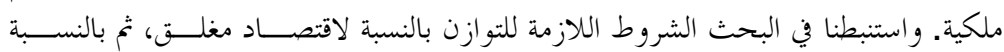

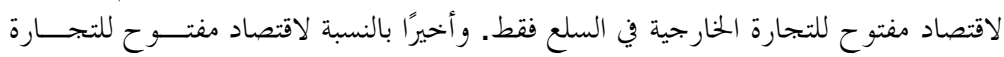
الخارجية في السلع والأسهم معًا.

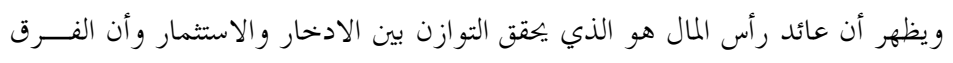

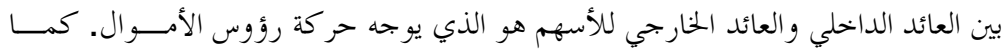

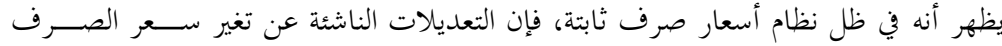

الخارجي تعمل من خلال حسابات الأصول. نابته فئن 